out the tendency of modern diplomacy in the hands of the aristocracy, whether of blood or of wealth, to emphasize the rivalries between nations at the expense of their solidarity of fundamental interests, and he asserts that progress in international relations will depend upon the control of foreign relations by a class of the community in closer touch with common life. The essay on the Entente policy discusses the influence of the Moroccan question in stimulating war-like feeling both in Germany and in France, as well as the effect of the Anglo-Russian entente in intensifying the rivalry between Germany and Great Britain in respect to the development of Asia Minor. A final chapter on "What our policy ought to have been" shows how on many points England pursued a policy of needless hostility to Germany and helped to increase the hold of militarism on German public opinion.

Arrangements have been made with the Macmillan Company for publishing the report of the Committee on Instruction of the American Political Science Association, presented at the Washington meeting in December, 1915. This will be issued in substantially the form of the report of the Committee of Seven of the American Historical Association; and it is expected that the volume will be on sale and ready for distribution by September 1 . This report should be of service, especially to teachers in the public schools and the smaller colleges.

\title{
DECISIONS OF AMERICAN COURTS ON POINTS OF PUBLIC LAW
}

\section{JOHN T. FITZPATRICK}

\section{Law Librarian, New York State Library}

Attorney's Fees-Act Imposing in Certain Cases. Sorenson vs. Webb. (Mississippi. March 27, 1916. 71 S. 273.) An act imposing a penalty in a reasonable attorney's fee upon every manufacturer for failure to pay his employees once in every month is unconstitutional as discriminating in favor of other classes of employers; there is no just and proper classification providing for the imposition of such a penalty upon manufacturers in contradistinction to other employers.

Divorce-Foreign Decree. Lister vs. Lister. (New Jersey. January 3,1916. 97 A. 170.) A decree of divorce by a court in Nevada undertaking to dispose of the status in respect of marriage of spouses 
not resident in that State is a nullity, as that State is powerless either by an act of its legislature or by a decree of one of its courts to fix the status of a person as married or unmarried when such person is only transient in that State but is actually a resident of New Jersey. There is no principle of comity which interferes with the power of the State of New Jersey to deny the right of a court of Nevada to determine the matrimonial status of such a person.

Employers' Liability Act-Jury. Minn. \& St. Louis R. R. vs. Bombolis. (United States. May 22, 1916. 241 U. S. 211.) The first ten amendments to the United States Constitution are not concerned with state action; a jury verdict in a state court in an action under the employers' liability act, which is not unanimous, but which is legal under the law of the State, is not illegal as violating the seventh amendment. While a state court may enforce a right created by a federal statute, such court does not by performing that duty derive its authority as a court from the United States but from the State; and the seventh amendment requiring a verdict by the common-law jury does not apply to it.

Employment Agencies-Licensing. Brazee vs. Michigan. (United States. May 22, 1916. 241 U. S. 340.) A state statute imposing a license fee to operate employment agencies and prohibiting employment agents from sending applicants to an employer who has not applied for labor, is not unconstitutional as depriving one operating an employment agency of his property without due process of law or as denying him equal protection of the laws.

Full Crews. St. L. \& Iron Mtn. Ry. vs. Arkansas. (United States. April 3, 1916. 240 U. S. 518.) The statute of Arkansas requiring full switching crews on railroads extending one hundred miles in length, is not unconstitutional as either depriving of property without due process of law or as denying equal protection of the law or as interfering with interstate commerce.

Gaming-Discrimination in Favor of Boards of Trade. Miller vs. Sincere. (Illinois. April 20, 1916. 112 N. E. 664.) A statutory provision for the recovery by the loser in any gaming, speculation or gambling device from the winner of the amount paid, except where the transaction is conducted through a regular board of trade, is invalid as 
being an unconstitutional discrimination between individuals engaged in the same business and granting special privileges and immunities to certain individuals.

Highways-Labor Thereon-Involuntary Servitude. Butler vs. Perry (United States. February 21, 1916. 240 U. S. 328.) A reasonable amount of work on public roads near his residenec is a part of the duty owed by an able-bodied man to the public; and a requirement by the State exacting such work does not amount to imposition of involuntary servitude within the prohibition of the thirteenth amendment; nor does the enforcement of such requirement deprive persons of their liberty and property without due process of law in violation of the fourteenth amendment. The object of the thirteenth amendment was liberty under protection of effective government and not destruction of the latter by depriving it of those essential powers which have always been properly exercised before its adoption. The term involuntary servitude as used in the thirteenth amendment was intended to cover those forms of compulsory labor akin to African slavery and not to interdict enforcement of duties owed by individuals to the State.

Income Tax-Constitutionality. Brushaber vs. Union Pac. R. R. (United States. January 24, 1916. 240 U. S. 1.) The income tax law of 1913 is not unconstitutional as violative of the sixteenth amendment. That amendment was obviously intended to simplify the tax situation and make clear the limitations upon the taxing power of Congress, and not to create radical and destructive changes in our constitutional system. The Constitution had recognized the two great classes of taxation as direct and indirect and applied the rule of apportionment as to the former and the rule of uniformity as to the latter. But by the sixteenth amendment all income taxes are now relieved from the rule of apportionment. Nor is the income tax law unconstitutional by reason of retroactive operation; nor as denying due process of law or equal protection of the law by reason of the classification therein of things or persons subject to the tax; nor because the provisions for collecting income at the source deny due process of law by reason of the duties imposed upon corporations without compensation in connection with the payment of the tax by others.

Income Tax-Taxation of Mining Corporations. Stanton vs. Baltic Mining Co. (United States. February 21, 1916. 240 U. S. 103.) 
There is no authority for taking taxation of mining corporations out of the rule established by the sixteenth amendment; nor is there any basis for the contention that, owing to inadequacy of the allowance for depreciation of ore body, the income tax is equivalent to one on the gross product of mines, and as such, a direct tax on the property itself, and therefore beyond the purview of that amendment and void for want of apportionment. Independently of the operation of the sixteenth amendment a tax on the product of a mine is not a tax upon property as such because of its ownership, but is a true excise levied on the result of the business of carrying on mining operations.

Labor-Right to Work as Property Right. Bogni vs. Perotti. (Massachusetts. May 19, 1916. 112 N. E. 853.) The act of 1914 declaring that the right to work shall no longer be a property right and prohibiting injunction in certain labor cases, is invalid as depriving the laborers of the equal protection of the laws, since it cuts off the right to resort to equity respecting the property right of laboring men and destroys the equality of laboring men with others. The right to work is property of which one cannot be deprived by a simple mandate of the legislature; and the mere fact that it is also a part of the liberty of the citizen does not affect its character as property.

Legislature-Determination of Election of Members. Dinan vs. Swig. (Massachusetts. April 6, 1916. 112 N. E. 91.) The act of 1913 requiring three judges of the superior court upon petition of voters to investigate an election, and upon finding any corrupt practice in the election of a member of the legislature, to enter a decree declaring the commission of a corrupt practice in his election and to certify the decree and declaration to the secretary of the commonwealth for transmission to the presiding office of the legislative body to which the defendant was elected, is violative of the prerogative vested exclusively in each branch of the general court which it alone can exercise and which it cannot delegate.

Monopolies. McFarland vs. American Sugar Co. (United States. April 24, 1916. 241 U. S. 79.) An act of the State of Louisiana relating to the business of refining sugar and creating the rebuttable presumption that any person systematically paying in that State a less price for sugar than he pays in any other State is a party to a monopoly or conspiracy in restraint of trade, is unconstitutional, the classifi- 
cation therein, if not confined to a single party, being so arbitrary as to be beyond possible justice, and the presumptions created having no foundation except on intent to destroy. The legislature may not declare an individual guilty or presumptively guilty of a crime.

Public Utility Commissioners-Powers. Public Service Elec. Co. vs. Board of Public Utility Commissioners. (New Jersey. March 6, 1916. 96 A. 1013.) The act conferring upon the board of public utility commissioners power to require every public utility to comply with the laws of the State and municipal ordinances and to conform to the duties imposed upon it thereby or by the provisions of its charter, does not confer upon the board the power to decree the specific performance of a contract; the latter is an equitable power exclusively inherent in the court of chancery; and even if the act in express terms had bestowed such a power upon the board, it would have been an unlawful invasion of the court's exclusive prerogative.

Removal of Causes to Federal Courts-Prohibition by States. Wisconsin vs. Phila. \& Reading Coal Co. (United States. May 22, 1916. 241 U. S. 329.) A provision of the state statute providing for the revocation of the license of a foreign corporation to do business within the State in case of removal, or application to remove, any action commenced against it by a citizen of that State to a federal court, is unconstitutional; the judicial power of the United States is a power wholly independent of state action, which the states may not directly of indirectly destroy, abridge or render inefficacious.

Rendition of Criminals between States. Innes vs. Tobin. (United States. February 21, 1916. 240 U. S. 127.) Prior to the adoption of the Constitution fugitives from justice were surrendered between States conformably to what were deemed to be the principles of comity. Article four of the Constitution is intended to embrace fully the subject of the rendition of such fugitives between the States and to confer upon congress authority to deal with that subject. Section 5278 of the revised statutes which was enacted by congress under the authority vested in it by the Constitution for the purpose of controlling interstate rendition was intended to be controlling and exclusive of state power; and this section expressly or by necessary implication prohibits the surrender in one State for removal as a fugitive from justice to another State of a person who clearly was not and 
could not have been such a fugitive from the demanding State. However, the doctrine of asylum applicable under international law, by which a person extradited from a foreign country cannot be tried for an offense other than the one for which the extradition was asked, does not apply to interstate rendition.

Taxation-Corporations-Interstate Commerce. Kansas City Ry. vs. Kansas. (United States. February 21, 1916. 240 U. S. 227.) The tax imposed by Kansas laws of 1913, chapter 135, on the privilege of being a corporation is not laid upon interstate commerce or receipts therefrom, fluctuating with the volume of interstate business, but is simply graduated according to paid up capital with a reasonable maximum; and it is not, as to a domestic corporation engaged in both interstate and intrastate commerce, inval.d either as a violation of the commerce clause as taxing interstate commerce or of the due process clause of the fourteenth amendment as taxing property beyond the jurisdiction of the State.

Theaters-Right to Admission. Woollcott vs. Shubert. (New York. February 22, 1916. 111 N. E. 829.) Under the common law, the theater, though affected by public interest justifying licensing, is in no sense public property nor governed by the rule relative to common carriers or other public utilities, and the proprietor's right to and control of it is the same as that of any private citizen in his property and affairs, so that he may admit or exclude persons at his pleasure. The civil rights law of the State of New York providing that all persons shall be entitled to full and equal accommodation in all places of public accommodation or amusements and providing a penalty for violation in denying admission to citizens upon the ground of race, creed or color, does not destroy the common-law right to exclude persons from theaters where the rule of exclusion applies alike to all persons, and is not based on race, creed or color.

Torts-Jurisdiction of Causes of Action.-Actions under Statutes of Foreign Countries. Hanlon vs. Frederick Leyland \& Co. (Massachusetts. March 9, 1916. 111 N. E. 907.) An action to recover damages for a tort is transitory, and can be maintained wherever the wrongdoer can be found. So the plaintiff by comity will be permitted to maintain an action in the courts of this commonwealth, under an English statute allowing an action for tort, although no right of prop- 
erty, under the statute, was vested in the deceased which survives to his personal representative.

Trading Stamps-Constitutionality of Act Imposing Prohibitive License Taxes. Rast vs. Van Deman \& Lewis. (United States. March 6, 1916. 240 U. S. 342.) The act of the State of Florida of June 5, 1913, which imposes a state license tax of $\$ 500$ and a county license tax of $\$ 250$ upon any person, firm or corporation offering trading stamps or profit sharing certificates redeemable in premiums, the license fees imposed being in addition to any other license fees or taxes, is not unconstitutional even though the license taxes as imposed are prohibitory; the right to carry on business by using trading stamps is not so protected by the federal Constitution as to render a tax thereon a violation of the due process provision of the fourteenth amendment. The statute is not open to objection as depriving of liberty and property without due process of law on account of the severity of its penalties so as to intimidate against testing its legality. A classification based on differences between a business using and one not using such stamps is not so arbitrary as to deny equal protection of the law. A distinction in legislation does not deny equal protection of the laws if any state of facts can be conceived that will sustain it; and, even though such facts or their effect may be disputed, courts cannot arbitrate such differences of opinion. It is for the legislature to discern and correct evils not only of definite injury, but also such as are obstacles to greater public welfare if within legislative authority, as is the use of such stamps. See also Tanner vs. Little, 240 U. S. 369; Pitney vs. Washington, 240 U. S. 387; State vs. Underwood, 71 S. 513.

Weights and Measures. Armour \& Co. vs. North Dakota. (United States. April 3, 1916. 240 U. S. 510.) The net weight lard statute of North Dakota, which requires lard, when not sold in bulk, to be put up in containers holding a specified number of pounds net weight or even multiples thereof and labeled as specified, is not unconstitutional as denying equal protection of the law or as depriving of property without due process of law; nor is it, as to packages sent into the State and afterwards sold to consumers by retail, unconstitutional as an interference with interstate commerce. 